\title{
Designing a Logic Model to Inform Montessori Research
}

\author{
Brooke Taylor Culclasure, ${ }^{1}$ Carolyn J. Daoust, ${ }^{2}$ Sally Morris Cote, ${ }^{1}$ and Susan Zoll ${ }^{3}$ \\ ${ }^{1}$ Furman University \\ ${ }^{2}$ University of Kansas \\ ${ }^{3}$ Rhode Island College
}

Acknowledgments: The authors would like to acknowledge significant contributions of the Montessori Research Working Group to the development of this logic model. Starting in 2015, scholars interested in studying Montessori education have met on an annual basis in retreats funded by Sorenson Legacy Foundation, Brady Education Foundation, and Harold Simmons Foundation. The logic model is a direct result of the collaborations, feedback, and contributions of the members of the working group, including: Arya Ansari, University of Virginia; Abha R. Basargekar, University of Virginia; Ian Becker, University of Virginia; Paige Bray, University of Hartford; John Broome, University of Mary Washington; Katie Brown, National Center for Montessori in the Public Sector; Jade Caines Lee, University of New Hampshire; Luz Casquejo Johnston, Saint Mary's College of California; Jie Chen, University of Kansas; Jackie Cossentino, National Center for Montessori in the Public Sector; Brooke Culclasure, Furman University; Sharon Damore, DePaul University; Carolyn Daoust, University of Kansas; Mira Debs, Yale University; Christine Emeran, American Montessori Society; Ann Epstein, University of Wisconsin La Crosse; Ann-Marie Faria, American Institutes for Research; Steve Hughes, Association Montessori Internationale; Iheoma U. Iruka, HighScope Educational Research Foundation; Katie Keller Wood, University of Virginia; Neal Kingston, University of Kansas; Elida Laski, Boston College; Angeline Lillard, University of Virginia; Nancy Lindeman, Westminster College; Karen Manship, American Institutes for Research; Darlene Maxwell, Coker College; Maria McKenna, University of Notre Dame; Angela K. Murray, University of Kansas; Theodore Quinn, Wildflower Schools; Kevin Rathunde, University of Utah; Vanessa Rigaud, Xavier University; Josh Russell, University of Hartford; Laura Saylor, Mount Saint Joseph University; Anthony Setari, University of Massachusetts-Lowell; Tracey Sulak, Baylor University; Diane Talley, University of North Carolina Chapel Hill; Gay Ward, University of Wisconsin River Falls; Karye Wells, American Institutes for Research; Keith Whitescarver, National Center for Montessori in the Public Sector; Susan Zoll, Rhode Island College.

Keywords: Montessori education, logic models, logic modeling, Montessori research, Montessori evaluation

Abstract: Montessori education has a long history, but its recent growth in American public schools has led to increased interest in research efforts, particularly in exploring the potential of the Montessori experience to moderate the effects of poverty and in gathering data to evaluate public investment in Montessori schools. To assist research efforts, this paper introduces a comprehen- 
sive visual model, or logic model, that depicts the core components, underlying assumptions, and intended outcomes of the Montessori approach. Logic modeling, which results in a visual representation depicting the connections among a program's inputs, primary activities, and outcomes, is often used in program planning and research to provide a common framework from which to work. Developed over a 3-year period by a collaborative group of experienced Montessori researchers and practitioners, the Logic Model for Montessori Education presented in this paper is a valuable tool for researchers with the potential to lay a foundation across disciplines for future research that is both rigorous and systematic in its measurement of Montessori processes and outcomes.

Dr. Maria Montessori developed the Montessori Method over 100 years ago as a child-centered educational approach based on scientific observations of children from birth to adulthood. While a more complete treatment of the topic is provided later in this article, some of the necessary components for an authentic Montessori program include multiage groupings that foster peer learning, uninterrupted blocks of work time, and guided choice of work activities (Lillard, 2017). In addition, hands-on Montessori learning materials are carefully arranged and available for students' use in an aesthetically tended environment. No extrinsic rewards are offered or grades assigned, and children are encouraged to explore personal interests while widely engaging with others (Lillard, 2017).

In the last two decades, several studies have explored Montessori education and measured implementation and outcomes of participation in both the public and private sectors (Ansari \& Winsler, 2014; Brown \& Lewis, 2017; Byun, Blair, \& Pate, 2013; Culclasure, Fleming, \& Riga, 2018; Dohrmann, Nishida, Gartner, Lipsky, \& Grimm, 2007; Ervin, Wash, \& Mecca, 2010; Hanson, 2009; Lillard, 2012; Lillard \& Else-Quest, 2006; Lopata, Wallace, \& Finn, 2005; Peng \& Md-Yunus, 2014; Rathunde \& Csikszentmihalyi, 2005). While often demonstrating findings in favor of Montessori education, many of these studies have significant limitations, such as small sample sizes, questionable authenticity of Montessori implementation, and selection bias. Although a recent randomized controlled trial addressed many of these concerns (Lillard et al., 2017), the limitations of most existing studies and the small quantity of research on Montessori education as a whole relative to other educational models demonstrate the critical need for more-rigorous research focusing on Montessori implementation and the subsequent effect on students, teachers, families, and communities.

One way to address some of the limitations identified in prior studies and help increase the quantity of quality research is to develop a shared understanding of the core components of Montessori pedagogy, its underlying assumptions, and its intended outcomes. While Montessori education is not new, educational researchers have never had a widely accepted, peer-reviewed document or visual aid outlining critical Montessori elements to inform research designs that align with the philosophy and guide the work of those in the field. Thus, researchers and practitioners, recognizing this need, collaborated over the past 3 years to create a comprehensive Logic Model for Montessori Education that depicts the core components, underlying assumptions, and intended outcomes of the Montessori approach. This article further discusses the logic model development process and presents a logic model that has the potential to lay a foundation across disciplines for future research that is both rigorous and systematic in its measurement of Montessori processes and outcomes.

As evident from the more recent, rigorous studies (Culclasure et al., 2018; Lillard et al., 2017), Montessori programs implementing the model with fidelity may effect positive changes in the areas of academic, behavioral, and socioemotional outcomes among participating children. Researchers must continue to explore these and other outcomes in a way that creates a robust body of evidence built from a commonly held understanding of the Montessori approach and the best ways to measure the impact of the approach. The 
logic model introduced here can act as a common reference point and a guide for future researchers who aim to contribute to the field regardless of their familiarity with Montessori education.

\section{Why a Logic Model for Montessori Education?}

Logic models represent a powerful way to succinctly and clearly communicate the core components of a program or approach to communities of practitioners, researchers, and other stakeholders. The logic model can act as a collective reference point to reconcile conversations across different disciplines and audiences, providing a common language and starting point for understanding best practices and the ways variations in implementation can lead to differences in results. Additionally, they can increase access to information among audiences that do not have expertise in an area by reducing complex narratives and theories to a relatively basic flow diagram that is easy to engage with. In other words, logic models can help individuals see both the forest and the trees, providing an overall picture of what a multifaceted educational approach like Montessori aims to do, while at the same time allowing consideration of how each part of the approach affects the others.

From a research perspective, increasing understanding of core Montessori components and processes may lead to additional, intentional research collaboration. Establishing a shared understanding of the intended outcomes of Montessori education can facilitate a conversation among researchers about how to standardize outcome operationalization and measurement. One of the main limitations to prior research on Montessori education is the lack of comparability between study methodologies and results. At present, Montessori research operates, essentially, in a research vacuum in which data comparison across studies is difficult. Data gathered using the same outcome definitions and measurement tools could be synthesized to create a foundation on which future studies can build, thus enabling researchers to more easily and accurately identify and attribute data inconsistencies to program implementation rather than to outcome measurement.

Modeling the Montessori process also opens the door to multiple research opportunities and pathways. Logic modeling explicates both core program components and processes (that clearly articulate the relationships among program outputs, outcomes, and impacts) in ways that can inform research questions for both process and impact studies. Process evaluations examine the fidelity of program implementation regarding the original program model, while impact evaluations assess whether the program had the intended effect on program participants. A Montessori logic model serves as an invaluable resource because it establishes the standard aspects of an authentic Montessori program and process. Researchers, particularly non-Montessorians, can use this model when designing research studies, allowing them to have a consistent understanding of authentic Montessori education, thereby avoiding potentially flawed research designs and subsequent faulty conclusions.

Logic models are meant to be dynamic resources that change in relation to the needs of program development, implementation, and research. In contrast to a prospective logic model —often used for planning how a new program should be implemented to effect changes - what is presented in this paper is a retrospective logic model for Montessori education. This retrospective model documents the process of authentic Montessori implementation and the intended outcomes for children as those outcomes are currently agreed upon by experts in the field. In addition to increasing understanding of Montessori education and facilitating future rigorous research, this logic model can be used prospectively in updating the Montessori approach as the collective understanding of precisely how Montessori education affects students is strengthened. Additionally, increasing access to the components of the Montessori logic model will help potential adopters weigh its costs and benefits compared to other existing educational models. 


\section{The Components of the Logic Model for Montessori Education}

Widely used in the worlds of program planning and evaluation, logic modeling is a systematic process of iteratively examining and documenting how and under which conditions a program or approach works. The result is a visual representation that depicts the connections among a program's Inputs/Resources, Activities/Actions, Outputs, the Outcomes the program intends to affect, and the overall, big-picture Impacts. When read from left to right (see Figure 1), logic models present the flow of how a program works over time from the acquisition of resources and funding to the implementation of core activities intended to result in desired changes (W. K. Kellogg Foundation, 2004). Inputs/Resources and Activities/Actions identify planned work, while Outputs, Outcomes, and Impacts trace intended results. The following discussion provides a brief overview of each component of a logic model, along with examples of potential research opportunities specific to Montessori contexts.

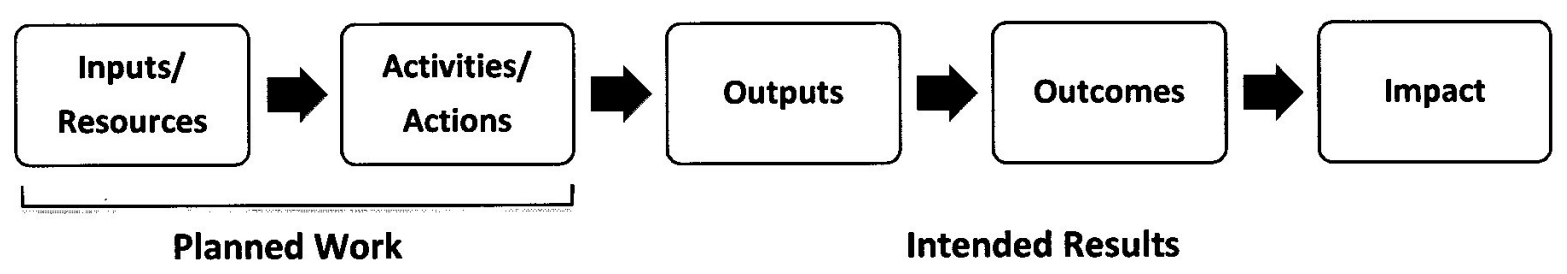

Figure 1. Basic logic model adapted from W. K. Kellogg Foundation, 2004.

Inputs/Resources, according to the W. K. Kellogg's Logic Model Development Guide, are the "human, financial, organizational, and community resources a program has available to direct toward doing the work" (p. 2). This encompasses everything from funding and staff to office space, technology, curriculum, and professional development. One input specific to Montessori classrooms is the didactic materials designed to promote students' concentration, independence, and self-correction. Researchers may elect to study an array of instructional materials not found in traditional classrooms that are designed to support a child's learning and development across a host of domains (e.g., language, literacy, math, science, geography). Also, similar to other education research, the actions and dispositions of teachers and their interactions with students are key areas of research to better understand student outcomes within a Montessori context.

Activities/Actions describe how a program uses inputs and resources to achieve program objectives; Activities/Actions are the actual processes and events used to bring about intended results. A critical Montessori activity for achieving authentic implementation is individualized learning within an ordered environment that delivers an integrated curriculum. Researchers could examine the processes embedded within Montessori classrooms that are designed to facilitate integrated curriculum delivery and individualized learning.

Outputs are the measurable, tangible, and direct results of Activities/Actions, usually described in terms of the size, frequency, and/or scope of the services or products delivered or produced. Examples in Montessori education include the number of children participating in Montessori programs who are ready to move to the next level of their education. Note that outputs do not communicate anything about the quality of the direct results from an activity or action.

Outcomes are the intended, short-term changes (i.e., 3 to 5 years) in program participants" "behavior, knowledge, skills, status, and level of functioning" (W. K. Kellogg, 2004, p. 2). Outcomes also can be examined at the systems level in terms of changes in condition or action, such as changes in organizational culture or policy. In Montessori schools, the expected outcomes are participant oriented, focusing on cultivating student behaviors, beliefs, and attitudes. Examples of the student outcomes from participation 
in authentic Montessori programs that researchers can examine include increased executive function, creativity, and academic achievement (Brown \& Lewis, 2017; Culclasure et al., 2018; Lillard, 2012; Lillard \& Else-Quest, 2006; Lillard et al., 2017).

Impacts are long-term and follow the achievement of outcomes over a sustained period (W. K. Kellogg Foundation, 2004). Impacts take 7 to 10 years to manifest and should not be expected to be seen in any significant way in the short term. In the logic model presented in this paper, we propose that children who participate in authentic Montessori programs over a long period of time should develop into physically healthy and mentally and psychologically fulfilled young adults who are highly educated and active participants in their communities.

\section{The Development of the Logic Model for Montessori Education}

The process of creating a new logic model is as valuable as the resulting model, just as the process of examining an existing one adds substantial value. When done systematically and with an openness to discovery, engaging with logic models helps researchers surface the assumptions that underlie their logic, assumptions that are critical to consider when trying to understand exactly how or under which conditions a program or educational approach works. A key assumption identified in the logic model presented here is that learner interest in a topic is one of the primary drivers of motivation and learning. If student interest is not piqued through varied learning methods, students will not develop a love of learning or the motivation to become a lifelong learner. Thus, motivation in Montessori classrooms is a prime area for further investigation.

As Martin and Carey (2014) detailed in their article about logic model development, documentation of the model creation and validation process is one of the most valuable aspects of the exercise because of the refined conceptual understanding that emerges. The clarity of thinking that results from building the logic model is critical to the overall success and eventual utility of the model (W. K. Kellogg Foundation, 2004).

As a primary part of the logic model development process, educators and researchers should first collaborate to develop a theory of change to describe the planned intervention that will bring about change in an educational setting. A theory of change is "a comprehensive description and illustration of how and why a desired change is expected to happen in a particular context" (Center for Theory of Change, 2017). Dhillon and Vaca (2018) described the theory of change as a roadmap, "providing pathways of outcomes... causally link(ing) inputs and activities to a chain of intended, observable outcomes" (p. 65). Using a backward design strategy to begin this process, stakeholders should first ground the theory of change in proposed outcomes that will be realized after an intervention is implemented. Once the project's outcomes are clearly articulated, the stakeholders may then develop detailed descriptions for each of the project's activities, listing required materials, personnel, and financial or community resources needed to ensure the intervention's success (W. K. Kellogg Foundation, 2017).

The idea for the development of a logic model for Montessori education was first discussed during the convening of the 2015 Montessori Research Working Group in Salt Lake City, UT. Several researchers new to the Montessori field who attended this convening of multidisciplinary researchers expressed the need for a logic model or similar tool to help them understand the core components of Montessori education and to provide a common language for understanding best practices and expected outcomes. Since no such logic model or tool existed, the development of a logic model for Montessori education was added as a priority task for the Montessori Research Working Group, and a Montessori Logic Model subgroup was created to develop the model.

Subsequently, under the leadership of this subgroup, the process included multiple steps over 3 years, with the input of numerous researchers and Montessori content-area experts. Six experienced Montessori teacher educators from both Association Montessori Internationale (AMI) and American Montessori Society (AMS) programs provided in-depth feedback on all sections of the first draft of the model through 
an online survey. Next, researchers circulated drafts of the logic model at various Montessori professional conferences and gatherings over the 3-year period and obtained verbal and written feedback from diverse groups of participants. Feedback from researchers, teacher educators, and practitioners resulted in continual refinements to the model through 2019, when it was deemed ready for publication. The timeline in Table 1 outlines the key steps of the process and the associated timeframe. Details about development of each section follow.

Table 1

Timeline of Logic Model Development Activities

Date Activity

October 2015

November 2015

March 2016

November 2016

Winter 2017

March 2017

Spring/Summer 2017

September 2017

November 2017

December 2017

May 2018

November 2018

January-April 2019
The MRWG forms a Montessori Logic Model subgroup. (Westminster College, Salt Lake City, UT)

Subgroup begins model development.

First draft is completed, shared with subgroup, and revised; drafts are circulated at AMS conference, and feedback is obtained. (Chicago, IL)

Subgroup convenes at the MRWG's annual meeting and discusses further revisions and reformatting the model. (Westminster College, Salt Lake City, UT)

Model is substantially revised (e.g., inputs are shortened, resources, actions, and outputs within and across program levels are added, and assumptions redone as key concepts and applications).

Drafts are circulated at AMS conference, and feedback is obtained. (San Diego, CA)

Feedback is obtained from Montessori teacher educators individually and at the International Montessori Congress; feedback is then integrated into the model. (Prague, Czech Republic)

Infant/toddler level is added to the model.

Feedback is provided by MRWG during the annual meeting. (University of Kansas, Lawrence)

Montessori infant/toddler teacher educators provide input; section is revised, and input is gathered at the MACTE symposium. (Alexandria, $\mathrm{VA})$

Logic model MRWG subgroup meets virtually, and a final draft is created.

Minor revisions are made during MRWG's annual meeting. (University of Kansas, Lawrence)

Process is documented and all references needed for theory of change are compiled; model is finalized for publication.

Note. MRWG = Montessori Research Working Group; AMS = American Montessori Society; MACTE = Montessori Accreditation Council for Teacher Education. 


\section{Inputs Section}

The Inputs/Resources section was shortened to Inputs in the Montessori logic model, and an initial list of 10 inputs was created by analyzing Montessori standards across time as outlined by professional Montessori organizations and by identifying areas of consensus (see Table 2). Each input was examined in relation to Dr. Montessori's writings, the writings of Montessori experts, and research on Montessori implementation, as shown in Table 2. Subsequently, the inputs were refined when the model was revised and an eleventh input was added to reflect Montessori education's inclusiveness.

Table 2

Resources for Inputs Section

Source type

Source type

Montessori professional organizational standards

Dr. Montessori’s writings

Montessori experts

Research on Montessori implementation
Sources

Association Montessori International/USA, 2009; American Montessori Society, 2014; Montessori Australia Foundation Limited, 2012; Montessori Public Policy Initiative, 2015; National Center for Montessori in the Public Sector, 2015

Montessori, 1912/1964; Montessori, 1914/1965; Montessori, 1917/1965; Montessori, 1939/1966; Montessori, 1948/1973; Montessori, 1948/1976; Montessori, 1956/1970; Montessori, 1962/1988; Montessori, 1967/1989; Montessori, 1976;

Montessori, 1997; Montessori, 2000;

Montessori, 2008

Boehnlein, 1988; Chattin-McNichols, 1992; Daoust, 2004; Feez, Miller, \& Tyne, 2012; Kahn, n.d.; A. S. Lillard, 2017; P. P. Lillard, 1972; P. P. Lillard, 1980; P. P. Lillard, 1996; Pedersen \& Pedersen, 2008; Pottish-Lewis, 2011; Rambusch \& Stoops, 1992; Standing, 1957/1984

Ansari \& Winsler, 2014; Byun, Blair, \& Pate, 2013; Culclasure, Fleming, \& Riga, 2018; Dohrmann, Nishida, Gartner, Lipsky, \& Grimm, 2007; Hanson, 2009; Lillard, 2012; Lillard \& Else-Quest, 2006; Lopata, Wallace, \& Finn, 2005; Peng \& Md-Yunus, 2014; Rathunde \& Csikszentmihalyi, 2005

\section{Key Concepts, Applications, Overall Impact, and Programming Across Levels Sections}

Experienced Montessori practitioners and researchers at all levels examined Montessori professional organizational standards, Dr. Montessori's writings, and the writings of content experts over a 3-year period to create the model's Key Concepts, Applications, and Overall Impact sections, as well as the Programming Across Levels section, as illustrated in Table 3. Expanded programming sections clearly articulate both similarities and differences in resources, actions, and goals across the range of age levels served by Montessori programs. 
Table 3

Resources for Key Concepts, Applications, Overall Impact, and Programming Across Levels Sections

\begin{tabular}{ll}
\hline \multicolumn{1}{c}{ Source type } & \multicolumn{1}{c}{ Sources } \\
\hline $\begin{array}{l}\text { Montessori professional organizational } \\
\text { standards }\end{array}$ & $\begin{array}{l}\text { Association Montessori International/USA, 2009; } \\
\text { American Montessori Society, 2014; Montessori Public } \\
\text { Policy Initiative, 2015; National Center for Montessori in } \\
\text { the Public Sector, 2015 }\end{array}$ \\
& Montessori, 1912/1964; Montessori, 1914/1965; \\
& Montessori, 1917/1965; Montessori, 1939/1966; \\
Dr. Montessori's writings & Montessori, 1948/1973; Montessori, 1948/1976; \\
& $\begin{array}{l}\text { Montessori, 1956/1970; Montessori, 1962/1988; } \\
\text { 1997; Montessori, 2000; Montessori, 2008 }\end{array}$ \\
& Boehnlein, 1988; Chattin-McNichols, 1992; Feez, Miller, \\
& \& Tyne, 2012; Kahn, n.d.; Lillard, 1972; Lillard, 1996; \\
& Lillard, 2017; Pedersen \& Pedersen, 2008; Pottish-Lewis, \\
& 2011; Rambusch, \& Stoops, 1992; Standing, 1957/1984 \\
\hline
\end{tabular}

\section{Outputs, Expected Outcomes, and Suggested Assessments Sections}

It must be noted that an Outputs section was not included in this more comprehensive logic model because outputs are typically more useful at individual program levels. The Outcomes section of the logic model (renamed Expected Outcomes and Suggested Assessments) includes expectations of enhanced executive function, heightened creativity and self-expression, increased motivation, strong social fluency, and emotional flexibility and advanced self-regulation skills. These outcomes were identified following a comprehensive review of the literature outlined in Table 3. The Suggested Assessments section was added so that appropriate and commonly used measures are listed in the logic model for each expected outcome. Instruments are organized by the types of outcomes they are designed to measure in Table 4.

These instruments represent examples of assessment tools across the breadth of nonacademic and academic outcomes expected from Montessori experience using measures that are also appropriate for use in non-Montessori contexts. These suggested assessments, while not exhaustive, represent a compilation of instruments recommended by experts in research, measurement, and assessment, including instruments previously used in Montessori studies with reasonable success. Table 5 summarizes specific recent studies according to which measure was incorporated. 
Table 4

Suggested Assements Organized by Expected Outcomes

\begin{tabular}{|c|c|}
\hline Expected outcomes & Suggested assessments \\
\hline Executive function & $\begin{array}{l}\text { Carlson \& Zelazo, 2017; Gershon \& Wagster, 2010a; } \\
\text { Gioia, Isquith, Guy, \& Kenworthy, 2000; Ponitz, } \\
\text { McClelland, Matthews, \& Morrison, } 2009\end{array}$ \\
\hline Creativity and self-expression & $\begin{array}{l}\text { Lubart, Besançon, \& Barbot, 2011; Meisels, Jablon, } \\
\text { Dichtelmiller, \& Marsden, 2015; Torrance, } 2010\end{array}$ \\
\hline Motivation & ACT, 2012 \\
\hline Social fluency and emotional flexibility & $\begin{array}{l}\text { Bronson, 2000; Gershon \& Wagster, 2010b; Gresham \& } \\
\text { Elliott, 2008; Squires, Potter, \& Bricker, } 1995\end{array}$ \\
\hline Self-regulation & $\begin{array}{l}\text { Gershon \& Wagster, 2010c; LeBuffe, Shapiro, \& } \\
\text { Robitaille, } 2018\end{array}$ \\
\hline Academic performance & $\begin{array}{l}\text { Dunn \& Dunn, 2007; Gershon \& Wagster, 2010d; Janus, } \\
\text { Offord, \& Mustard, 1999; Bracken, 2006; NWEA, } 2019\end{array}$ \\
\hline Cognition and general development & $\begin{array}{l}\text { Gershon \& Wagster, 2010a; Schrank, McGrew, \& Mather, } \\
\text { 2014; Squires, Potter, \& Bricker, } 1995\end{array}$ \\
\hline
\end{tabular}

Table 5

Studies Organized by Suggested Assessments Used

\begin{tabular}{ll}
\hline \multicolumn{1}{c}{ Suggested assessment } & \multicolumn{1}{c}{ Studies } \\
\hline ASQ-3 & Tobin et al., 2015 \\
BRIEF & $\begin{array}{l}\text { Bagby, Barnard-Brak, Sulak, Jones, \& Walter, 2012; Culclasure, } \\
\text { Fleming, \& Riga, 2018 }\end{array}$ \\
EPoC & Cossentino \& Brown, 2014; Culclasure et al., 2018 \\
HTKS & Culclasure et al., 2018; A. S. Lillard, 2012; A. S. Lillard, 2017; \\
MEFS & A. S. Lillard et al., 2017; Lillard \& Heise, 2016 \\
NIH Cognition Battery & Cossentino \& Brown, 2014; Culclasure et al., 2018 \\
NIH Flanker & Phillips-Silver \& Daza, 2018 \\
Student Record Database & Culclasure et al., 2018; Phillips-Silver \& Daza, 2018 \\
\hline
\end{tabular}




\begin{tabular}{ll}
\hline SSWH & Ervin et al., 2010 \\
TTCT & Besançon, Lubart, \& Barbot, 2013 \\
WJ III/IV & Lillard \& Heise, 2016
\end{tabular}

Note. ASQ-3 = Ages \& Stages Questionnaire; BRIEF = Behavior Rating of Inventory of Executive Function; $\mathrm{EPoC}=$ Evaluation du Potentiel; HTKS = Head-Toes-Knees-Shoulder Task; MEFS = Minnesota Executive Function Scale; NIH Cognition Battery = NIH Toolbox Cognition Battery; NIH Flanker $=$ NIH Toolbox Flanker Inhibitory Control \& Attention Test; SSWH = Social Skills and Work Habits; TTCT = The Torrance Tests of Creative Thinking; WJ III/IV = Woodcock-Johnson III/IV.

\section{The Logic Model for Montessori Education}

Figure 2 is the culmination of the work outlined in the previous sections and presents a graphic display of critical components of the logic model. It is important to note that this logic model is a living document, and it is expected that subsequent versions of the logic model, supported by the most current research, will be published in the future. A downloadable version of the logic model and its associated references is available in the Supplementary Materials.

\section{Conclusions and Future Directions}

Regarding future directions and considerations for subsequent versions of the logic model, more work should be done in several areas. For example, peace education and some aspects of social justice are deeply rooted within Montessori pedagogy (Debs, 2019; Duckworth, 2008). Therefore, an expanded treatment of the potential of Montessori as a vehicle to ensure equitable learning opportunities is warranted. Such an examination will require deeper consideration of bias, equity, and human rights in all aspects of the Montessori approach to ensure that all children are able to equally thrive and benefit from Montessori education.

The logic model presented in this paper is a valuable tool for researchers seeking to study Montessori education, as it has the potential to lay a foundation across disciplines for research that is both rigorous and systematic in its measurement of Montessori processes and outcomes. While constant work is required to ensure the logic model remains updated and reflects the most current research, this first version provides a solid foundation from which researchers and practitioners can work and continue to build.

\section{AUTHOR INFORMATION $\dagger$ Corresponding Author}

Brooke Culclasure $\uparrow$ is research director of Furman University's Richard W. Riley Institute and can be reached at brooke.culclasure@,furman.edu.

Carolyn Daoust is a research associate at the University of Kansas Center for Montessori Research.

Sally Morris Cote is the Richard W. Riley Institute at Furman University's director of Planning and Evaluation Capacity Building.

Susan Zoll is an associate professor in elementary education at Rhode Island College as well as the director of the Institute of Early Childhood Teaching and Learning at Rhode Island College. 


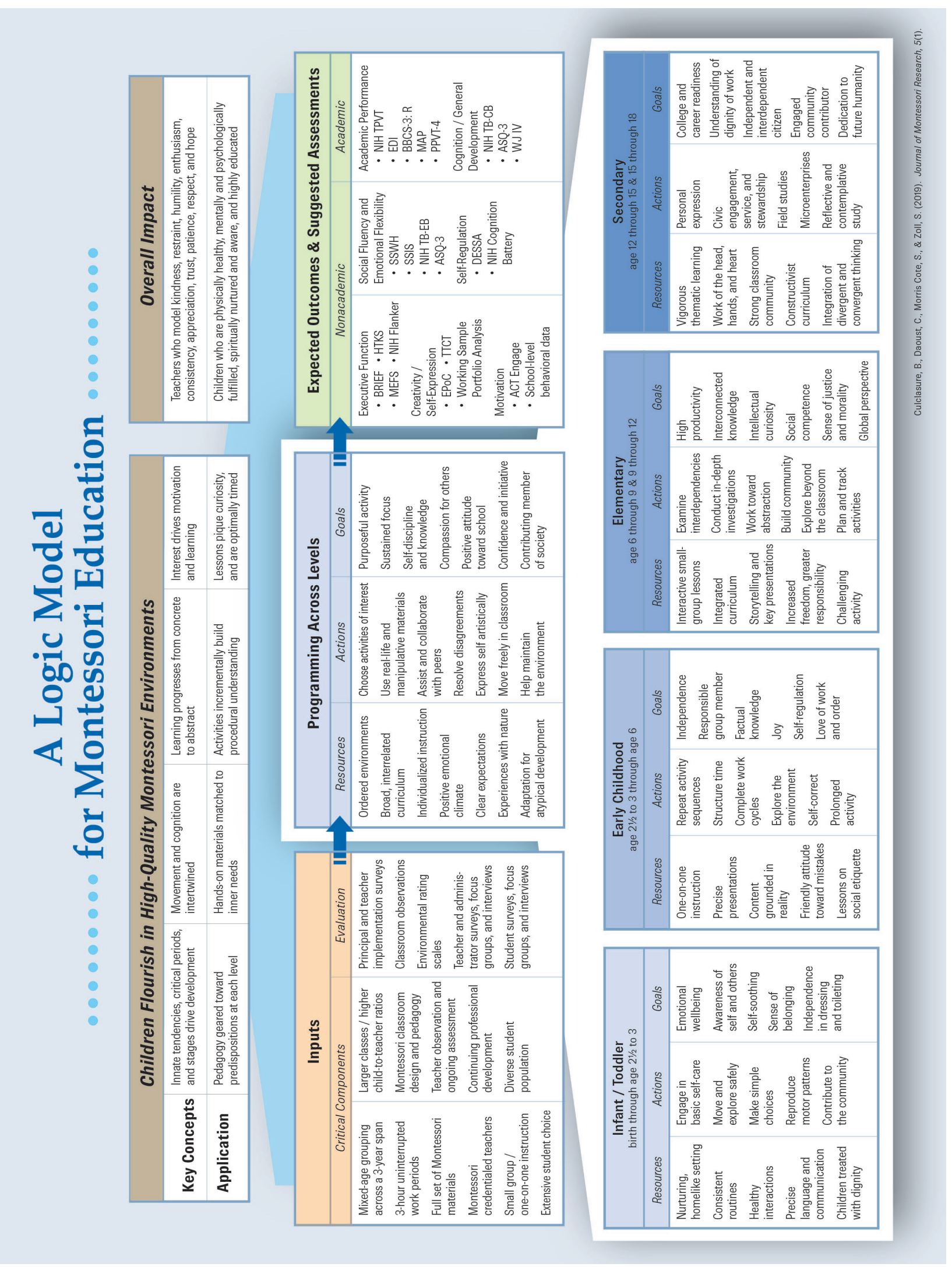

Figure 2. A Logic Model for Montessori Education. 


\section{References}

ACT. (2012). ACT Engage [Assessment instrument]. Iowa City, IA: Author. Retrieved from https://www. act.org/content/act/en/products-and-services/act-engage/about-act-engage.html

American Montessori Society. (2014). AMS school accreditation standards and criteria. Retrieved from https://amshq.org/Educators/Montessori-Schools/AMS-Accreditation/Accreditation-Standards

Ansari, A., \& Winsler, A. (2014). Montessori public school pre-K programs and the school readiness of low-income Black and Latino children. Journal of Educational Psychology, 106, 1066-1079.

Association Montessori International/USA. (2009). AMI/USA Montessori school standards. Alexandria, VA: Author.

Bagby, J., Barnard-Brak, L., Sulak, T., Jones, N., \& Walter, M. (2012). The effects of environment on children's executive function: A study of three private schools. Journal of Research in Childhood Education, 26, 418-426. doi:10.1080/02568543.2012.711431

Besançon, M., Lubart, T., \& Barbot, B. (2013). Creative giftedness and educational opportunities. Educational and Child Psychology, 30(2), 79-88. doi:10.1080/03004279.2015.1020643

Boehnlein, M. M. (1988). Montessori research analysis in retrospect [Preface]. The NAMTA Journal, 13(3).

Bracken, B. (2006). Bracken Basic Concept Scale Third Edition: Receptive [Assessment instrument]. Bloomington, MN: Pearson Assessments, Inc. Retrieved from https://www.pearsonassessments.com/ store/usassessments/en/Store/Professional-Assessments/Developmental-Early-Childhood/BrackenBasic-Concept-Scale-\%7C-Third-Edition\%3A-Receptive/p/100000225.html

Bronson, M. B. (2000). Self-regulation in early childhood. New York, NY: The Guilford Press.

Brown, K. E., \& Lewis, C. W. (2017). A comparison of reading and math achievement for African American third grade students in Montessori and other magnet schools. Journal of Negro Education, 86, 439-448.

Byun, W., Blair, S. N., \& Pate, R. R. (2013). Objectively measured sedentary behavior in preschool children: Comparison between Montessori and traditional preschools. International Journal of Behavioral Nutrition and Physical Activity, 10(2), 1-7.

Carlson, S., \& Zelazo, P. (2017). Minnesota Executive Function Scale [Assessment instrument]. St. Paul, MN: Reflection Sciences, Inc. Retrieved from https://reflectionsciences.com/mefs-app/

Center for Theory of Change. (2017). What is theory of change? Retrieved from http://www.theoryofchange. org/what-is-theory-of-change/

Chattin-McNichols, J. (1992). The Montessori controversy. Albany, NY: Delmar Publishers.

Cossentino, J., \& Brown, K. (2014). Assessing creativity and critical thinking in schools: Montessori as a holistic intervention. AMI Journal, 2014-2015. Retrieved from https://public-montessori.org/wpcontent/uploads/2016/10/Assessing-Creativity-and-Critical-Thinking-in-Schools-Cossentino-andBrown.pdf

Culclasure, B., Fleming, D. J., Riga, G. (2018). An evaluation of Montessori education in South Carolina's public schools. The Riley Institute at Furman University, Greenville, SC. Unpublished manuscript. Retrieved from https://riley.furman.edu/sites/default/files/docs/MontessoriOverallResultsFINAL.pdf

Daoust, C. J. (2004). An examination of implementation practices in Montessori early childhood education (Doctoral dissertation). Retrieved from Proquest Dissertations \& Theses Global. (305212045)

Debs, M. (2019). Diverse families, desirable schools: Public Montessori in the era of school choice. Boston, MA: Harvard Education Press.

Dhillon, L., \& Vaca, S. (2018). Refining theories of change. Journal of MultiDisciplinary Evaluation, 14(30), 64-87. Retrieved from http://journals.sfu.ca/jmde/index.php/jmde_1/article/view/496/444

Dohrmann, K. R., Nishida, T. K., Gartner, A., Lipsky, D. K., \& Grimm, K. (2007). High school outcomes for students in a public Montessori program. Journal of Research in Childhood Education, 22, 205-217.

Duckworth, C. (2008). Maria Montessori's contribution to peace education in Teachers College. In M. Bajaj (Ed.), Encyclopedia of peace education. Columbia University. Retrieved from https://www. tc.columbia.edu/epe/epe-entries/Duckworth_ch4_22feb08.pdf

Dunn, L., \& Dunn, D. (2007). Peabody Picture Vocabulary Test Fourth Edition [Assessment instrument]. 
Bloomington, MN: Pearson Assessments, Inc. Retrieved from https:/www.pearsonassessments.com/ store/usassessments/en/Store/Professional-Assessments/Academic-Learning/Brief/Peabody-PictureVocabulary-Test-\%7C-Fourth-Edition/p/100000501.html

Ervin, B., Wash, P. D., \& Mecca, M. E. (2010). A3-year study of self-regulation in Montessori and non-Montessori classrooms. Montessori Life, 22(2), 22-31.

Feez, S., Miller, J., \& Tyne, M. (2012). A national Montessori curriculum report. The North American Montessori Teachers' Association (NAMTA) Journal Special Issue, 37(1), 1-307.

Gershon, R., \& Wagster, M. (2010a). NIH Toolbox Cognition Battery [Assessment instruments]. Bethesda, MD: National Institutes of Health. Retrieved from http://www.healthmeasures.net/exploremeasurement-systems/nih-toolbox

Gershon, R., \& Wagster, M.(2010b). NIH Toolbox Emotion Battery [Assessment instruments]. Bethesda, MD: National Institutes of Health. Retrieved from http://www.healthmeasures.net/explore-measurementsystems/nih-toolbox

Gershon, R., \& Wagster, M. (2010c). NIH Toolbox Flanker Inhibitory Control \& Attention Test [Assessment instrument]. Bethesda, MD: National Institutes of Health. Retrieved from http://www.healthmeasures. net/explore-measurement-systems/nih-toolbox

Gershon, R., \& Wagster, M. (2010d). NIH Picture Vocabulary Test [Assessment instrument]. Bethesda, MD: National Institutes of Health. Retrieved from http://www.healthmeasures.net/explore-measurementsystems/nih-toolbox

Gresham, F., \& Elliott, S. (2008). Social Skills Improvement System Rating Scales [Assessment instrument]. Bloomington, MN: Pearson Assessments, Inc. Retrieved from https://www.pearsonassessments.com/ store/usassessments/en/Store/Professional-Assessments/Behavior/Social-Skills-Improvement-SystemSSIS-Rating-Scales/p/100000322.html

Gioia, G., Isquith, P., Guy, S., \& Kenworthy, L. (2000). Behavior Rating of Inventory of Executive Function [Assessment instrument]. Lutz, FL: PAR, Inc. Retrieved from https://www.parinc.com/Products/ Pkey/23

Hanson, B. E. E. (2009). An exploratory study on the effectiveness of Montessori constructs and traditional teaching methodology as change agents to increase academic achievement of elementary Black students (Doctoral dissertation). Retrieved from ProQuest Dissertations \& Theses Global. (305164185)

Janus, M., Offord, D., \& Mustard, F. (1999). Early Development Instrument [Assessment instrument]. Hamilton, Canada: McMaster University. Retrieved from https://edi.offordcentre.com/

Kahn, D. (n.d.). Ten steps to Montessori implementation in public schools. North American Montessori Teachers Association. Retrieved from http://www.montessori-namta.org/Montessori-Implementation

LeBuffe, P., Shapiro, V., \& Robitaille, J. (2018). The Devereux Student Strengths Assessment [Assessment instrument]. Fort Mill, SC: Aperture Education, Inc. Retrieved from https://apertureed.com/

Lillard, A. S. (2012). Preschool children's development in classic Montessori, supplemented Montessori, and conventional programs. Journal of School Psychology, 50(3), 379-401. doi:10.1016/j.jsp.2012.01.001

Lillard, A. S. (2017). Montessori: The science behind the genius. New York, NY: Oxford University Press.

Lillard, A., \& Else-Quest, N. (2006). Evaluating Montessori education. Science, 313, 1893-1894.

Lillard, A. S., \& Heise, M. J. (2016). Removing supplementary materials from Montessori classrooms changed child outcomes. Journal of Montessori Research, 2(1). doi:10.17161/jomr.v2i1.5678.

Lillard, A. S., Heise, M. J., Richey, E. M., Tong, X., Hart, A., \& Bray, P. M. (2017). Montessori preschool elevates and equalizes child outcomes: A longitudinal study. Frontiers in Psychology, 8. doi:10.3389/ fpsyg.2017.01783

Lillard, P. P. (1972). Montessori: A modern approach. New York, NY: Schocken.

Lillard, P. P. (1980). Montessori in the classroom. New York, NY: Schocken.

Lillard, P. P. (1996). Montessori today. New York, NY: Schocken.

Lopata, C., Wallace, N. V., \& Finn, K. V. (2005). Comparison of academic achievement between Montessori and traditional education programs. Journal of Research in Childhood Education, 20(1), 5-13. 
Lubart, T., Besançon, M., \& Barbot, B. (2011). Evaluation du Potentiel Créatif [Assessment instrument]. Paris, France: Editions Hogrefe France. Retrieved from https://www.hogrefe.fr/produit/epoc-evaluationdu-potentiel-creatif-des-enfants/

Martin, I., \& Carey, J. (2014). Development of a logic model to guide evaluations of the ASCA national model for school counseling programs. Professional Counselor, 4, 455-466.

Meisels, S., Jablon, J., Dichtelmiller, M., \& Marsden, D. (2015). Work Sampling System [Assessment instrument]. Bloomington, MN: Pearson Assessments, Inc. Retrieved from https://www. pearsonassessments.com/campaign/wso-for-nyc.html

Montessori, M. (1912/1964). The Montessori Method. New York, NY: Schocken.

Montessori, M. (1914/1965). Dr. Montessori's own handbook. New York, NY: Schocken.

Montessori, M. (1917/1965). Spontaneous activity in education: The advanced Montessori Method. Madras, India: Kalakshetra Publications.

Montessori, M. (1939/1966). The secret of childhood. New York, NY: Ballantine Books.

Montessori, M. (1948/1973). To educate the human potential. Madras, India: Kalakshetra Publications.

Montessori, M. (1948/1976). From childhood to adolescence. New York, NY: Schocken.

Montessori, M. (1956/1970). The child in the family. New York, NY: Avon.

Montessori, M. (1962/1988). The discovery of the child. Oxford, England: Clio Press.

Montessori, M. (1967/1989). The absorbent mind. New York, NY: Dell Publishing.

Montessori, M. (1976). Education for human development. New York, NY: Schocken.

Montessori, M. (1997). Basic ideas of Montessori's educational theory: Extracts from Maria Montessori's writings and teachings. Oxford, England: ABC-Clio.

Montessori, M. (2000). The California lectures of Maria Montessori, 2015. Oxford, England: Clio.

Montessori, M. (2008). The child, society, and the world: Unpublished speeches and writings. Amsterdam, the Netherlands: Montessori-Pierson Publishing Company.

Montessori Public Policy Initiative. (2015). Montessori essentials. Retrieved from https://www. montessoriadvocacy.org/resources

National Center for Montessori in the Public Sector. (2015). Essential elements on Montessori practice in the public sector. Retrieved from http://www.public-montessori.org/resources/ncmps-rubric-essentialelements-montessori-practice-public-sector

NWEA. (2019). Measures of Academic Progress [Assessment instrument]. Portland, OR: Author. Retrieved from https://www.nwea.org/map-growth/

Pedersen, H., \& Pedersen, J. (2008). What is Montessori? A basic guide to the principles, practices, and benefits of a Montessori education. San Anselmo, CA: Sandpiper Press.

Peng, H., \& Md-Yunus, S. (2014). Do children in Montessori schools perform better in the achievement test? A Taiwanese perspective. International Journal of Early Childhood, 46, 299-311.

Phillips-Silver, J., \& Daza, M. T. (2018). Cognitive control at age 3: Evaluating executive functions in equitable Montessori preschool. Frontiers in Education, 3, 1-8. doi:10.3389/feduc.2018.00106

Ponitz, C., McClelland, M., Matthews, J., \& Morrison, F. (2009). Head-Toes-Knees-Shoulder Task [Assessment instrument]. Charlottesville: University of Virginia Social Development Lab. Retrieved from http://www.socialdevelopmentlab.org/resources/measures/htks/

Pottish-Lewis, P. (2011). Elementary classroom management: How to implement cosmic education. Rochester, NY: Association Montessori International/USA.

Rambusch, N. M., \& Stoops, J. A. (1992). The authentic American Montessori school: A guide to the selfstudy, evaluation, and accreditation of American schools committed to Montessori education. New York, NY: American Montessori Society and the Commission on Elementary Schools of the Middle States Association.

Rathunde, K., \& Csikszentmihalyi, M. (2005). Middle school students' motivation and quality of experience: A comparison of Montessori and traditional school environments. American Journal of Education, 111, 341-371. 
Schrank, F. A., McGrew, K. S., \& Mather, N. (2014). Woodcock-Johnson IV [Assessment instrument]. Rolling Meadows, IL: Riverside Insights. Retrieved from https://www.riverside-assessments.com/wjiv Squires, J., Potter, L., \& Bricker, D. (1995). Ages and Stages Questionnaire [Assessment instrument]. Baltimore, MD: Paul H. Brookes Publishing. Retrieved from https://products.brookespublishing.com/ Ages-Stages-Questionnaires-Third-Edition-ASQ-3-P569.aspx

Standing, E. M. (1957/1984). Maria Montessori: Her life and work. New York, NY: New American Library. Tobin, T., Boulmier, P., Zhu, W., Hancock, P., \& Muennig, P. (2015). Improving outcomes for refugee children: A case study on the impact of Montessori education along the Thai-Burma border. International Education Journal: Comparative Perspectives, 14, 138-145. Retrieved from http://openjournals. library.usyd.edu.au/index.php/IEJ/index

Torrance, E. P. (2010). The Torrance Tests of Creative Thinking [Assessment instrument]. Bensenville, IL: Scholastic Testing Service, Inc. Retrieved from https://www.ststesting.com/gift/

W. K. Kellogg Foundation. (2004). Logic model development guide. Retrieved from http://www.wkkf.org/ knowledge-center/resources/2006/02/wk-kellogg-foundation-logic-model-development-guide.aspx

W. K. Kellogg Foundation. (2017). The step-by-step guide to evaluation: How to become a savvy evaluation consumer. Battle Creek, MI: Author. 